\title{
Relationship-Courier Partner Logistics and E-Commerce Enterprises in Malaysia: A Review
}

\author{
Nurul Izzah*, Damhuji Rifai and Liu Yao \\ Faculty of Industrial Management, Universiti Malaysia Pahang, Gambang, Kuantan, Pahang, Malaysia; \\ damiza87@gmail.com,damhuji@tatiuc.edu.my, liuyao@ump.edu.my
}

\begin{abstract}
Background/Objectives: The term "logistics services and e-commerce" have been in use for more than 10 years, but has recently become an important subject of analysis and empirical investigation. It is common in Malaysia in logistics services like courier services companies which they call customers for whom buy their services and for e-commerce enterprises that they call courier services companies as a business partner or Courier Partner Logistics (CPL) where CPL provided any logistics services for their business operations. This paper presents and reviews the milestone and development of logistics operations in courier services companies and e-commerce enterprises in Malaysia. This paper also will show the relationship between both of them which are logistics/courier services companies and e-commerce enterprises. Methods/Analysis: We use a qualitative and quantitative method such as interview and observation (qualitative) to verify of questionnaires (quantitative) this study by experts in the field of logistics especially in courier firms and e-commerce enterprises. Findings: In reviewing literature we find that online users in Malaysia are greater than Singapore, but for Malaysia's e-commerce of retail only $0.2 \%$ compared than Singapore $1.0 \%$. It means entrepreneurs in Malaysia still not aware in utilization and advantages of Internet or ICT in their business. In Asian countries, most of among them are still in initial stage to the development of e-business, especially Malaysia, but for e-commerce level companies Malaysia, they also try to show good performances and advanced with assistance and support by Malaysia government such as Multimedia Development Corporation (MDeC) and efficiency of logistics by courier companies within product delivery service provider, so this is one way to e-commerce enterprises develop business towards to e-business level. Applications: In conclusion, it could help to acknowledge the current levels management and ability as well as the role of logistics/courier services and e-commerce enterprises' performances. Thus, it could guide both of them to renew their perceptions of the effects of the managing knowledge operations and services to better develop and also enhance their operational practices. So, both of them could survive their business to compete with others competitors. In addition, the significance of this study and benefit for future research is clearly known about the relationship strength between them (relationship among the two industries namely courier services companies and e-commerce enterprises' performances).
\end{abstract}

Keywords: Courier Services Companies, Development, E-Commerce Enterprises, Logistics Operations, Malaysia

\section{Introduction}

The logistics industry is a crucial facilitator of Malaysia's growing trade and strong economic growth. It is important as an enabler of the nation's trade-dependent and exportoriented economy which cannot be overemphasized. The market demand for logistics facilities and services in
Malaysia from industrial parks, free zones, warehouses/ depots and distribution parks has been increasing year by year. In essence, the demand stems from the urgent need for companies to be competitive and to thrive in their marketplace by delivering the right products at the lowest cost if possible, in the right quantity, in the right place and at the right time ${ }^{1}$. Logistics service providers emerge

\footnotetext{
${ }^{*}$ Author for correspondence
} 
to enable the smooth, safe and cost efficient movement of goods and resources along the supply chain ${ }^{2}$. With the advancement of Information and Communication Technologies (ICT) in the recent decades, businesses have been creatively extended to be conducted over the Internet or transferred to be the so-called e-business which has been convinced that promising new avenues for the creation of wealth with its fast growing and robust momentum characteristics.

\section{Milestone of Logistics Service and Development of E-Commerce in Malaysia}

In the courier services industry side, service quality is among the most crucial determinant for customer satisfaction $^{3,4}$. They are one of logistics service providers in supply chain management in which to serve delivery goods and parcels from wholesaler or retailers to consumers directly ${ }^{5}$.

Malaysia's logistics operations development in courier services begins with the establishment of the courier services company by Pos Malaysia Bhd (which called Pos Malaysia in the following) by the government that could be traced back to the early 1800s. The postal service was set up first in the Straits Settlements (Penang, Malacca and Singapore) and gradually grew to cover the other parts of Malaya by the early 20th century. In the 1980s, Malaysia's logistic industry embraced two local private companies namely Nationwide in 1985 and ABX Express in 1986. Coming to the 1990s, logistics industry in Malaysia became more competitive as more private companies even from overseas were added in such as Kangaroo Worldwide Express, GD Express, SkyNet and etc. To a better compete with those private entrants, Pos Malaysia was corporatized from the Postal Services Department (PSD) in 1992 and was listed on the Kuala Lumpur Stock Exchange by September 2001.

On the other hand, e-commerce development in Malaysia started around 1998 with the incorporation of Lelong which is arguably regarded as the biggest local e-business company in this moment. Followed in 2004, eBay launched service in Malaysia through ebay.com.my. In 2005, Mobile88 launched iPay88 which the Malaysia's number one online payment provider to date. Year by year, more local and international e-commerce companies enter Malaysia. For example, Lelong in 2009 launched its
Business-to-Customers (B2C) shopping mall (Superbuy. com), PayPal started supporting Ringgit Malaysia in the same year and Pos Malaysia also launched its B2C shopping mall (PostMe.com) in 2010. In 2011, PostMe. com and Gmarket started venturing in Malaysia then followed by Rocket Internet (which owns shareholdings in Zalora, Lazada and Foodpanda) and Rakuten.

Due to the booming demand, in 2011, Logistic Service Providers (LSP) began offering Cash on Delivery (CoD) into e-commerce activities to support their customers especially for courier services. Review of logistics operations and courier service milestones and e-commerce development in Malaysia which can be referred in Table 1, e-commerce seems to only started to blossom in Malaysia since 2011.

At the same time, in 2011, LSPs began offering CoD into e-commerce activities to ease their customers. But for those among Malaysian, they are still not confident with online payment. So, first courier's services company that offer CoD such as YAMATO Ta-Q-Bin (M) and GD Express (which called GDex in the following). On 25 September 2011, YAMATO has launched its CoD service in Malaysia which the first of its kind in Malaysia. YAMATO accept customer to pay on the spot when customers are receiving the parcel. Customers can pay to the Ta-Q-Bin personnel when they visited customers at their doorstep. Ta-Q-Bin personnel will contact customers on the delivery date and time, so they can prepare the money in advance. This is a true of $\mathrm{CoD}$ service where YAMATO deliver the parcel to customers' doorsteps and they make the payment only when they are receiving the parcel.

When the demand in the delivery of e-commerce companies increased, GDex also took an opportunity to launch the CoD. So, customers can make payment to GDex personnel only when receiving the goods. After that, GDex makes the payment to the e-commerce company where they picked up the goods and e-commerce companies will then incur a service charge. Moreover, PayPal officially opens global operation centres in Malaysia which further facilitates the online transactions for joint development of both e-commerce enterprises and logistics service. Hence, the year 2011 witnesses a creative climax between logistics services and e-commerce industries in Malaysia.

Certainly, from the year onwards, Malaysia's logistics operation and courier services have promptly increased the number of branches. Example, Pos Malaysia which has not only covered Malaysia but also expanded to other 
Table 1. Milestone of logistics service and development of e-commerce in Malaysia

Milestone of Logistics Service
Pos Malaysia Bhd established as a public company for
first postal service in Malaysia.
Nationwide Express
ABX Express
Logistics Companies:
Kangaroo Worldwide Express, GD Express
Pos Malaysia Bhd privatized
Pos Malaysia Bhd. listed on Kuala Lumpur Stock Ex-
change (KLSE or now it is called as Bursa Malaysia Bhd)

Pos Malaysia Bhd. launched PostMe.com.

Japan logistics, YAMATO Ta-Q-Bin launch at Malaysia and they are offering COD for the first time in Malaysia logistics operation. Then, followed other logistics companies like GD Express, Sky Net, Nationwide Express etc.

$\begin{array}{cc}\text { Year } & \text { Development of E-Commerce } \\ 1867 & \\ 1985 & \\ 1997 & \\ 1992 & \text { Incorporation of Lelong as a first of e-commerce in Malaysia } \\ 2001 & \text { iPay88 launch } \\ 2004 & \text { Pelong launches B2C through Superbuy (lelong.com) and } \\ 2005 & \text { PayPal supports Malaysia Ringgit (MYR) } \\ 2009 & \text { Pos Malaysia Bhd. take the opportunity when e-commerce } \\ 2010 & \text { and service of logistics become important in each other, so } \\ & \text { its role as a logistics company number one in Malaysia where } \\ \text { they launched B2C through PostMe.com. }\end{array}$

2011 The demand of goods delivery from e-commerce companies increased. Logistics service providers offer COD to ease for e-business's customers.

Asia countries with the support of payment online and also existence $\mathrm{CoD}$. With the $\mathrm{CoD}$ customers for the first time experience by using online shopping on which they start to have more confidence and trust. Thus, $\mathrm{CoD}$ is regarded as one successful case of creativity that simplifies logistics service and promotes safety to buy online. Another example of creative practice is the TV home shopping, which launched by GoShop in 2014. In 2015, GoShop further added channels for online shopping in order to satisfy the huge demand from Malaysian internet users for shopping in anywhere at any time. We believe that there are many more creative practices that happened in either logistics service companies or e-commerce companies or both, where they are boosting both parties towards a win-win prosperous and enhance their business performances together.

Furthermore, the logistics are not confined to manufacturing alone. Not disputed that it is relevant to all enterprises including government, institutions and services organizations such as wholesalers and retailers like e-commerce enterprises where they sell any product via online through an enterprise website without face to face with their customer. For this activity, they really need LSP for courier service companies to deliver goods to the consumer.

The LSPs is a company that provides management over the flow of goods and materials between points of origin to end-use destination ${ }^{6,7}$. The provider will often handle shipping, inventory, warehousing, packaging and security functions for shipments ${ }^{6}$. Essentially, courier service companies are one of from LSP but they more focussed on finished product delivery to consumers ${ }^{7}$. Therefore, this study would define of logistics management as a supply of logistics services to other companies (e-commerce enterprises) and for their consumers through the use of integrated information, knowledge and secure transaction that covered the whole logistic warehouse management which from inbound management to outbound management. 


\section{Courier Services}

The efficient delivery and pick-up of items, such as parcels and/or documents are a core operation of any courier service. Challenging characteristics related to this operation include: First, the delivery network changes daily; second, there is real-time customer demand for pickup during delivery; third, there is an increasing trend for courier companies to provide micro-logistics services which including deliveries of high-value items in small size such as cellular phone sets or internet connection packages. These latter services are not necessarily of the "next day" type, but delivery may be performed within a certain pre-agreed period ${ }^{8}$.

\subsection{Definitions of Courier Services}

Generally postal and courier services are services that are assigned to carry documents, parcels or other items from one place to another quickly and efficiently. Services offered by the postal and courier services are listed in Table 2. The process of postal and courier services comprises the process of collecting mail at the collection center, sorting the mail base on location delivery destination, the movement of mail to ensure timely delivery of mail and distribute the mail to the delivery destination". Implementation Communication Technology (ICT) in the process of postal and courier services help drastically the efficiency of mail delivery process to ensure that the correct mail can be received by the customer on time.

The difference of courier service with regular mail service is the speed of parcels or document delivery to the customer, the safety of delivery process that requires the signature and stamp of the company received as proof of mail delivery. As a premium service, couriers are usually more expensive than regular postal service. However, the speed of the delivery process and the security courier services remain an option for the delivery of goods that are important and require immediate delivery.

Courier companies provide services on all scales, from city to city, regional delivery services and global service. There are many international courier company that provides courier services through a network of companies that use a hub and spoke model ${ }^{10}$. Among these courier companies including DHL, FedEx, OCS, DTDC, TNT, International EMS, UPS and Aramex.

Therefore, we try to define courier services as a business partner that logistic services e-business trust with delivering important parcels for e-business buyers to improve e-business performances from image business side, enhance profit side, through good cooperation and technology of courier services, as good as possible the services they (logistics and courier) giving for e-business companies.

At this time, the postal industry has been an envelope and the services offered are not limited to the parcel delivery. New services such as courier services, e-services and transport services have been introduced to diversify and broaden the scope of the offer services. Emerging technology based on the convergence of e-communication and publishing will and has continued to change the landscape of postal industries in terms of the services provides by courier and postal company through new system model ${ }^{10-12}$.

Courier services with the latest technology will allow customers to monitor the delivery processes in realtime tracking. Technologies such as barcode scanning and signature capture will speed up the delivery process. With advanced mobile device applications, tracking the delivery of parcels or document can be continuously monitored at each stage of the delivery process. This system can increase customer confidence in courier service and improve customer service.

The good of courier services is backed by collecting creative ability and managing knowledge to develop innovation. It is important to solve issues of critical customer services where including practical practices which in technical support and application training with the participation of whole of employees, where the features are such as client management, customize billing, rates and services to suit customers' specific needs. Client management is also included contract billing, sales tracking, electronic notifications, invoicing and built-in collections tool ${ }^{13,14}$.

The courier company can track the exact location of their drivers significantly with the delivery tracking system that uses Global Positioning System applications (GPS). This system allows managers courier companies warn their drivers and the dispatchers if a delivery "almost late" or late. Courier manager can arrange and manage the driver rotation system for the delivery process to optimize the cost of transportation.

Besides that, the delivery pricing must be competitive and flexible. The delivery pricing must be user-friendly and affordable rates to the value of goods, delivery distance and the of heavy parcels. Pricing system using 
zone systems such as zone-heavy, zone-count or doorto-door distance provide comfort feel to the customer to use of courier services. For delivery outside the delivery zone system, surcharges can be implemented which the rate should be base on the distance the delivery. The right pricing plan must be given automatically to provide confidence to customers ${ }^{15}$. Courier company's financial management system should be managed professionally includes able to provide a variety of management reports such as performance analysis and results.

The role of the courier services is very important to support e-commerce company's development. To assist e-commerce companies with efficient courier service today, the Courier Services Provider should provide the customer with customer web portal to trace and track the orders and delivery notification through email. The effective of delivery process will help customer confidence to support the development of e-commerce companies ${ }^{16}$.

Therefore, this study tries to define courier services as a business partner that person you trust with delivering important parcels for your buyers to improve your business from image business side, enhance profit side, through good cooperation and technology of courier services as well as possible the services they giving for your business.

\subsection{Malaysia's Courier Services}

One of the service sector that is continues growing is a courier services sector. In 2008, global package delivery reached a value of USD 500 million and is expected to continue to increase $\mathrm{e}^{17}{ }^{18}$. Participation of Malaysia in the Trans-Pacific Partnership Agreement (TPPA) is expected to boost the courier service sector by $20 \%$ within the next 5 years. The Courier services are expected to reach $£ 4$ billion in 2020. Table 2 shows the list of courier company operates at Malaysia in $2015^{8}$.

However, this industry faces challenges of managing knowledge and creativity in services as a result of globalization. Although, the Malaysia's courier market has grown at $7 \%$ annually in average, the existence and growth of logistics management companies from private companies in Malaysia (refer Table 2), this industry has numerous challenges ahead in terms of access to expert capital, managing of knowledge in administration, services and operations and creative ability to innovative services.

Malaysia still needs continuous learning and research to develop postally and courier service management more competitive. For example, the European Courier, Express and Parcel (CEP) sector is a very strategic and dynamic sector involved in globalization. Primarily, the CEP sector

Table 2. List of logistics management companies and courier service companies in Malaysia year 2015

\begin{tabular}{lc}
\hline Malaysia Courier Services Companies & Services \\
\hline Poslaju EMS (National Service) & Courier delivery services. \\
Nationwide Express & Courier delivery services. \\
FedEx & Courier and freight. \\
Skynet Worldwide & Courier delivery services. \\
GD Express & Express Delivery Service. \\
AirAsia Courier & International delivery express, overland transport and air freight. \\
Avanti Worldwide Express AWE & International delivery express. \\
City-Link & Courier delivery services. \\
DHL Worldwide Express & Express Delivery Service, International delivery express, Logistics and warehouse. \\
DPEX & Courier delivery services and International delivery. \\
Kangaroo & Courier delivery services and International delivery. \\
Malaysian Express Worldwide & Air freight, International delivery and warehouse. \\
S.O.S. Express (SOS Transportation) & Overseas Courier Service OCS and Logistics Provider. \\
Sure-Reach Worldwide Express & Courier delivery services. \\
TNT Express Worldwide & Logistics Provider, Local and international courier delivery services. \\
YAMATO Ta-q-bin Malaysia Sdn Bhd & warehousing, international courier delivery services, transportation and distribution man- \\
& agement. \\
UPS Malaysia-United Parcel Service & Courier delivery services. \\
\hline
\end{tabular}


is a separate activity from the postal service ${ }^{19}$. Nowadays, Malaysia courier services regardless of their sizes face with the challenges dealing with the new technologies from a business partner, with operating in the same way as private corporations ${ }^{9}$, understanding what products are profitable and which are not and dealing with almost constant change in business based on e-commerce environment.

To continues survive, Malaysia's courier services companies need to change through managing of efficient knowledge to become more competitive in services and operations and also market-oriented (e-commerce) and customer-driven (end consumers). In this environment, the price is no longer the only determinant of the courier industry ${ }^{20}$. Speed and quality or knowledge responsiveness among staff to customers is the next source of competitive advantage, especially in the courier industry. The creativity and improvement can develop when Malaysia's courier services companies know what their customer really need to follow the current situation.

\section{E-Commerce}

E-commerce usually refers to the distribution, marketing, sales, track and trace online and services electronically. The term of electronic commerce has been used to describe a wide range of transactions in the online market, where information technology helps each operation and business transactions through electronic networks. In the past, a dominant firm in the value chain typically put out a network that deployed proprietary applications over this private network. For example, Chrysler, Ford and General Motors put up a network and required all its parts and sub-assembly suppliers to participate in its Electronic Data Interchange (EDI) over the network ${ }^{21}$.

The emergence of the Internet as a public network with a lot of utilized by millions of people online has created a new interactive market for buying and selling. Thus, part of e-commerce means the ability to buy and sell items, the ability to deliver marketing information and online services through the public network ${ }^{22}$.

The tremendous growth of e-commerce can be attributed to the reduction of friction in business transactions via online networks. This reduction has led to such an increase in service quality, customer satisfaction, lower costs in business operations, faster transaction including the delivery of physical goods by Logistics Service Providers and prompt delivery of goods in some cases such as software or digital music ${ }^{23}$.

E-commerce consists of a system for processing business transactions and operations it's to support the company, such as the creation of sources of information, movement information through a global network, an efficient and effective interaction among producers, consumers, intermediaries and sellers. Besides, e-commerce can perform daily economic activities such as pricing, contracts, payments and also track and trace online to facilitate the delivery of goods from the courier company ${ }^{24}$.

Thus, for e-commerce companies we refer to buying and selling goods and services on the Internet, especially through the website as it is known by the name World Wide Web (www). In practice, this term and a newer term, e-business is often used interchangeably, in which that organization has adopted Intranet and Extranet as a whole.

\subsection{E-commerce Enterprises in Malaysia}

According to BBC News on December 2014, the Malaysia only began to use the Internet as the main platform at around 1995. Improvements continue to be made by the Malaysian government, until 2010, the government has given high-speed internet access, it is accessible and affordable to all Malaysians. Facilities such as WiMAX is the first $4 \mathrm{G}$ technology and is provided by the Malaysian government to offer mobile internet with faster speed, large capacity and no need high cost. As of second quarter of 2015, Malaysia has broadband penetration rates of 91.7 (per 100 inhabitants) and 72.2 (per 100 households). Malaysia average internet speed is 5.0 Megabits per second (Mbps) and shows a $17 \%$ year-on-year improvement in broadband speed. Malaysia is ranked 70th place worldwide by 2015 State of the Internet (Soti).

Unfortunately, Malaysia can be considered as the country lagging behind in Internet use widely. Although already a few years since the commercialization of the Internet, Malaysians still regard it as a new platform, most of them associate the internet only with communications and entertainment industries, but not as a medium for commerce. So, in the late 2000s, e-commerce in Malaysia is still in its infancy ${ }^{25,26}$. Conduct transactions online, Malaysia is still not as popular as in western countries. Although almost every Internet users in Malaysia surveyed said they generally like the idea of shopping on the internet. The fact, only a small number of Malaysians buying trough online ${ }^{27}$. Approximately $96 \%$ of adults 
living in urban Peninsular Malaysia never buy anything via the Internet and only $4 \%$ have done so. In the last 10 years (2000-2010), Malaysians are still not comfortable with the use of the Internet for applications such as shopping and banking. It still has not become a way of life in Malaysia.

But from 2010-2015, Malaysians began to be comfortable with using the internet for e-commerce applications due to the Internet speed more advanced, cheaper and it is a trend or lifestyle not only for the young user but all of the age level. It is proved by Razaleigh Zainal as a Vice President, Corporate Communications Ad Marketing of $\mathrm{MDeC}$ where he confirmed in his twitter on date 28 October 2015 that MyCyberSale 2015 has surpassed the total Gross Merchandise Value (GMV a.k.a Revenue) target by $18 \%$ achieving RM117.13 million in the 5 days event which double of the year 2014's revenue ${ }^{20,28}$.

E-commerce enterprises allow consumers to shop electronically, it can be done at anytime and anywhere without the restrictions of time or distance. E-commerce has grown rapidly in the last five years and in subsequent years, it is expected to show superior performance with a faster pace ${ }^{28,29}$. In the near future, the boundaries between "conventional" and "electronic" commerce will become increasingly blurred as more and more entrepreneurs are turning to the Internet for their business operations. As $\mathrm{B} 2 \mathrm{~B}$, it refers to electronic commerce between businesses rather than between businesses and consumers. B2B businesses often deal with hundreds or even thousands of other businesses, either as customers or suppliers, including logistics service providers as a logistics provider. If it is much more demanding and more complex in cooperation between businesses to other business via electronic, e-commerce enterprises will be e-business activities. They are dependent on each other for completing their operation and management. Therefore, this study will explore the activities of e-commerce and e-business companies which they always need the logistics management and services by logistics service provider such as in warehouse management and process of goods delivering. Conduct transactions electronically provide great competitive advantages over traditional methods. When implemented properly, e-commerce provides advantages in business operations such as faster, cheaper and easier than traditional methods of bartering goods and services.

Electronic transactions have been around for a long time such as in the form of Electronic Data Interchange (EDI). EDI requires each supplier and customer to establish a link between their specific data where e-commerce provides a cost, this method is very effective for companies that have many links.

E-commerce has also led to the development of the electronic market place where suppliers and potential customers together conduct mutually beneficial trade. To create a successful online store can be difficult if you do not know the principles of e-commerce and what e-commerce should do for companies as a business online. Read and understand the correct guidelines and appropriate, where is the implementation of e-business plan is an essential part of success in developing the online store.

\section{Courier Service Companies and E-Commerce Enterprises}

Logistics management seeks to enhance competitive performance by closely integrating the internal functions within the company to other business and effectively linking them with the external operations of suppliers activities, customers requirement and other channel members (e.g. business partner) ${ }^{30}$. In another word, good organizational performance also comes from business partners (like courier services companies as a CPL to e-commerce enterprises) and customers perspective ${ }^{31 .}$ They are able to serve with best services to them and their business partner was satisfied and confident then would enhance their business partner enterprises ${ }^{32}$. Hence, this study implying that business partner and customer (e-commerce enterprises) always repeat use of logistics services in courier services companies. This situation shows that they have a symbiosis relation for both of them. They can enhance company performance together, where they have a good performance in the relationship to supply chain operations.

Logistics management is relevant to all types of organizations like courier services to serve e-commerce enterprises, so logistics are not confined to manufacturing operations alone ${ }^{33}$. Definitely, logistics management is relevant and related to all enterprises especially in retail management, large firm, Small and Medium Enterprises (SME) (seller/vendor or retailers) ${ }^{34-36}$.

Besides that, to build friendly alliances in the logistics service and business partner, collaboration in the logistics 
service presents multi-creative features and need a long time. The Logistics Service Providers should be sure that they have a flexible service to the retailers and wholesalers (e-commerce enterprise companies). So, knowledge management competence in quality supervision and coordination are critical to realizing successful joint in the logistics service. Therefore, this study implying that logistics/courier services which positively affects an e-commerce enterprises' performances.

\section{Discussion}

Studies of logistics management and operations in Malaysia for 5 years is still focused on the development of logistics ${ }^{32}$ and the efficiency of logistics services ${ }^{34}$. A study has been conducted on managing logistics operations, which this study focuses on courier services companies and their operations/services to e-commerce enterprises in Malaysia. In recent years, the possibility of applying efficient of managing knowledge to the logistics service like courier services companies and to logistics planning has been put forward in the literature of Malaysia academic. Despite these discussions was done before, managing knowledge has not been implemented in Malaysia's logistics in the scale of warehousing service, packaging service, delivery service and distribution service, track and trace online service with their partner like an e-commerce enterprises.

Due to no research and rare study about managing knowledge relating logistics operations or courier services, it would toward a Malaysia increase of e-commerce enterprises' performances. They are business partners in supply chain management, where courier services companies act as CPL for e-commerce enterprises.

Besides that, improvement of performance in e-commerce enterprise activities would impact on the logistics/courier services directly where dealer's e-commerce will be continued in their contract with logistics/courier services efficient ${ }^{32}$. The logistics outsourcing relationships between suppliers in the field of e-commerce especially retention which refers to renewing existing contracts under agreement details when they expire, while extension relates to expanding the volume or scope of an existing relationship by cross-selling and providing additional services for existing customers. The satisfaction and loyalty of e-commerce firm as their customers, it shows to what degree ability and proactive improvements can foster an existing relationship and to what extent such improvements may be leveraged outside toward other parties.

\section{Conclusion}

A frank dialogue or sharing interpretation about the information is required for all sides to arrive at a common understanding which is the foundation for integrated decision making and united action in an organization. Especially in Malaysia's logistics service industry, logisticsrelated knowledge management in service providers aims at improving the effectiveness of enterprises by raising the standards of efficiency of knowledge generation, dissemination, shared interpretation and responsiveness. As in companies and the society in general, knowledge has been widely recognized as information and accepted as a strategic resource in the area of logistics too.

Besides that, increased of e-commerce enterprise development, in their networks have created new needs in the logistics field. For example, the demand of different from e-business's customer which at the same time give a value-added service in logistics management is increasing. Before this, in the traditional way its status made it difficult to find services to fulfil these new needs.

This study tries to review that e-commerce enterprise development which can also improve the status of logistics operations and courier services in the future as the relevance, where it is significance for the development of the economy. This research is supposed to bring more insights to the effective managing of logistics/courier strategy or model especially in Malaysia and provide feasible managerial suggestions to both industry and government, which could contribute to the economic development of Malaysia.

Additionally, this study addresses competition with present the logistics operation and courier services as transportation and warehouse distribution drove in the logistics industry and the e-commerce enterprises as a technology which virtually driven in business marketing.

In conclusion, it could help to acknowledge the current levels of managing knowledge and achieve different ability as well as the role of logistics operation/ courier services and e-business performances. Thus, it could guide both of them to renew their perceptions of the effects of the managing knowledge, operations and services for a better develop and enhance their operational 
practices. So, both of them could survive their business to compete with others competitors. In addition, the significance of this study and benefit for future research is clearly to know about the relationship strength between them (relationship among the two industries namely logistics/courier services and e-commerce enterprises' performances) to enhance their performances from the financial and non-financial side.

\section{References}

1. Tian, Y, Ellinger AE, Chen H. Third-party logistics provider customer orientation and customer firm logistics improvement in China. International Journal of Physical Distribution and Logistics Management. 2010; 40:356-76.

2. Matayong S, Mahmood AK. KMS innovation decision making: The case study of oil and gas industry in Malaysia. 2011 Natl. Postgrad. Conf; 2011 Sep 19-20. p. 1-5. Doi: 10.1109/NatPC.2011.6136307.

3. Roslan NAA, Wahab E, Abdulla NH. Service Quality: A case study of logistics sector in Iskandar Malaysia using SERVQUAL Model. Procedia - Soc Behav Sci. 2015 Jan; 172:457-62.

4. Zailani S, Fernando Y, Zakaria H. Determinants of RFID adoption among Logistics Service Providers in Malaysia: a discriminant analysis. Int J Logist Syst Manag. 2010; 7(3):345-67.

5. Wallenburg CM,Lukassen P. Proactive improvement of logistics service providers as driver of customer loyalty. Eur J Mark. 2011; 45:438-54.

6. Othman A, Kari F, Jani R, Hamdan R. Factors influencing cooperative membership and share increment: An application of the logistic regression analysis in the Malaysian Cooperatives. World Rev Bus Res. 2012; 2:24-35.

7. Phan DD. E-business development for competitive advantages: A case study. Inf Manag. 2003 Jul; 40(6):581-90.

8. Ninikas G, Athanasopoulos T, Zeimpekis V, Minis I. Integrated planning in hybrid courier operations. Int J Logist Manag. 2014; 25:611-34.

9. Grunert T, Sebastian HJ. Planning models for long-haul operations of postal and express shipment companies. Eur J Oper Res. 2000 Apr; 122(2):289-309.

10. Cullen J, Tsamenyi M, Bernon M, Gorst J. Reverse logistics in the UK retail sector: A case study of the role of management accounting in driving organisational change. Manag Account Res. 2013 Sep; 24(3):212-27.

11. Sandelands E. Strategic logistics management. Int J Phys Distrib Logist Manag. 2013; 27:73-142.

12. Cullen J, Tsamenyi M, Bernon M, Gorst J. Reverse logistics in the UK retail sector: A case study of the role of management accounting in driving organisational change. Manag Account Res. 2013 Sep; 24(3):212-27.

13. Fernie J, Pfab F, Marchant C. Retail grocery logistics in the UK. Int J Logist Manag. 2000; 11(2):83-90.
14. Fernie J. Retail Change and retail logistics in the United Kingdom: Past trends and future prospects. Serv Ind J. 1997; 17(3):383-96.

15. Lin, C. et al. A decision support system for optimizing dynamic courier routing operations. Expert Syst Appl. 2014 Nov; 41(15):6917-33.

16. Chang TS,Yen HM. City-courier routing and scheduling problems. Eur J Oper Res. 2012 Dec; 223(2):489-98.

17. Fedorko G, Weiszer M, Borzecky M. The shipments flow simulation in courier company. Congress Proceedings CLC 2012: Carpathian Logistics Congress; 2012. p. 441-5.

18. Gouvea MA, Toledo GL, Filho LNR. The prices of mailing services evaluated by companies. Mark Intell Plan. 2001; 19(4):282-94.

19. Kunkel M, Doppstadt C, Schwind M. Open service-oriented computing for logistics: A case in courier, express and parcel networks. Lecture Notes in Computer Science (including subseries Lecture Notes in Artificial Intelligence and Lecture Notes in Bioinformatics), LNCS; 2010; 6275:134-44.

20. Khan MJ, Dominic PDD, Khan A,Naseebullah. Adoption of e-commerce in Malaysia and its affect on the business performance: An organizational perspective. Proceedings 2010 International Symposium on Information Technology - Visual Informatics, ITSim'10; Kuala Lumpur. 2010 Jun 15-17. p. 1-5.

21. Gol H, Catay B. Third-party logistics provider selection: Insights from a Turkish automotive company. Supply Chain Manag. An Int J. 2007; 12(6):379-84.

22. Jehangir M, Dominic PDD, Naseebullah N, Khan, A. Towards digital economy: The development of ICT and E-commerce in Malaysia. Mod Appl Sci. 2011 Apr; 5(2):171-78.

23. Office for National Statistics. E-commerce and information and communication technology (ICT) activity. 2008. Stat. Bull. 2009. p. 1-12.

24. Gunasekaran A, Ngai EW. Information systems in supply chain integration and management. Eur J Oper Res. 2004 Dec; 159(2):269-95.

25. Kenyon GN, Meixell MJ. Success factors and cost management strategies for logistics outsourcing. J Manag Mark Res. 2011 Mar; 7(1):1-17.

26. McGinnis MA, Kohn JW,Spillan JE. A longitudinal study of logistics strategy: 1990-2008. J Bus Logist. 2010; 31(1):217-35.

27. $\mathrm{Wu} \mathrm{JH}$, Hisa TL. Analysis of E-commerce innovation and impact: A hypercube model. Electronic Commerce Research and Applications. 2004; 3(4):389-404.

28. Khatibi A, Haque A, Karim K. E-Commerce: A study on Internet shopping in Malaysia. J Appl Sci. 2006; 6(3):696-705.

29. Kamaruzaman KN,Hanrich YM. e-Commerce Adoption in Malaysia: Trends, Issues and Opportunities. ICT Strateg Rev; 2010-2011. p. 89-134.

30. Singh N, Bartikowski BP. Global E-Commerce: A portal bridging the world markets. Int Bus. 2010 Feb; 11(1):1-5.

31. Sterba SK, MacCallum RC. Variability in parameter estimates and model fit across repeated allocations of items to parcels. Multivariate Behav Res. 2010 Mar; 45(2):322-58. 
32. Liu WH, Xie D, Xu XC. Quality supervision and coordination of logistic service supply chain under multi-period conditions. International Journal of Production Economics. 2013 Apr; 142(2):353-61.

33. Kersten W, Koch J. The effect of quality management on the service quality and business success of logistics service providers. Int J Qual Reliab Manag. 2010; 27(2):185-200.

34. Yu W, Jacobs MA, Salisbury WD, Enns H. The effects of supply chain integration on customer satisfaction and financial performance: An organizational learning perspective. Int J Prod Econ. 2013 Nov; 146(1):346-58.
35. Xu L, Wang K. Research on influence of chain store logistics capability to logistics service quality. 2010 International Conference on Logistics Engineering and Intelligent Transportation Systems, LEITS2010 - Proceedings; Wuhan. 2010 Nov 26-28. p. 1-4. Doi: 10.1109/LEITS.2010.5664986

36. Bollampally K, Dzever S. The impact of RFID on pharmaceutical supply chains: India, China and Europe Compared. Indian J Sci Technol. 2015 Feb; 8(S4):176-88. 